\title{
Medical partnership and primary care
}

\section{連携するプライマリ・ケア}

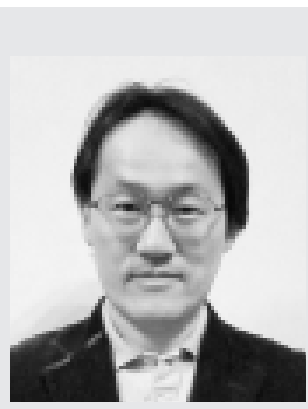

1987 年東京慈恵会医科大学卒．武蔵 野赤十字病院にて研修後, 東京都立府中 病院にて東京 $\mathrm{ER}$ ・府中に従事した。 2010 年 3 月より東京都立多摩総合医療 センター内科部長.

認定資格：日本内科学会認定総合内科専 門医・指導医, 日本消化器病学会指導医, 日本救急医学会救急科専門医, 日本消化 器内視鏡学会指導医, 日本プライマリ・ ケア連合学会認定指導医・代議員, 日本 緩和医療学会暫定指導医

研究テーマ: 態度教育

主な活動は, 緩和医療の標準化・臨床研 修環境の整備・医療人材の育成である.

\section{芝 祐信}

地域の医療資源の有効活用の観点から医療連携の重要性については論 を俟たない. 医療連携が常に円滑に進むとは限らない. 救急患者の入院 診療依頼, 退院患者の在宅診療依頼など, どのような事情があるにせよ, 連携がうまくいかないケース (1,2) $^{1}$ が確実に存在する。

急性期病院では, 病床稼働率を上げるために早期退院を目指し, 病床 利用率を上げるために病床を隅々まで有効活用するなど日々努力してい る。退院に際して様々な問題が起きる。早期退院の結果, 地域医療者へ の情報提供不足となる事例があとを絶たない。一方, 終末期がん患者が, 十分な時間があったにもかかわらず準備不足のまま退院となる事例も少 なくない" ${ }^{3)}$. どちらも効果的な医療連携がとれず，良質なプライマリ・ ケアが提供できない.

ほとんどの研修医は，2 年間の大半を病院医療者から手ほどきされて 成長する。地域保健・医療の研修として 1 力月の在宅医療を経験した研 修医 50 人の感想文を読み返してみた。 どの研修医も, 病院医療のなか では気付けなかった発見をしている，在宅医療の経験は研修医に変化を もたらす。

在宅医療の常識に精通した病院医療者は思いのほか少ない.このよう な環境ではどんなに長く研修しても教育効果には限界がある．在宅医療 を経験できなくても, 改善のためのフィードバックを地域医療者から受 けられる機会があるとよい，病院医療者と在宅医療者の顔が見える医療 連携であってほしい.

\section{文 献}

1）安田英己. 在宅医療におけるネットワーク構築. 家庭医プライマリ・ケ ア医入門, 家庭医療学研究会, プリメド社, 2001, p. 250-253

(医療における連携の必要度の格差. 連携上の留意点. 連携のためのルー ル作りと患者の意識改革の必要性)

2）前沢政次. プライマリ・ケアにおける連携の留意点. プライマリ・ケア実 践ハンドブック, 日本プライマリ・ケア学会, エルゼビア・ジャパン, 2004, p. $30-33$

(病院志向の患者・在宅医療に興味のない医師に関する問題. ネットワー ク構築の考え方)

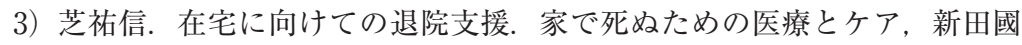
夫, 医歯薬出版, 2007, p. 20-26

(これから求められる病院医療者と退院支援における連携)

\footnotetext{
芝 祐信 (しば すけのぶ)

東京都立多摩総合医療センター内科

（＝183-8524＼cjkstart東京都府中市武蔵台 2-8-29 e-mail：sukenobu_shiba@tmhp.jp）
} 